\title{
The National Front Against Poverty: The Struggle for Income Redistribution ${ }^{1}$
}

\author{
Luis Ernesto Campos, CTA, Argentina
}

\begin{abstract}
This article describes the campaign developed by unions, human rights organisations and other social movements in Argentina at the end of the 1990s in order to push the government to implement measures to eliminate poverty and extreme poverty. It also refers to the results of this campaign in the following years, highlighting not only its direct impact but also its indirect consequences in the medium term, in particular on the public debates related to the social policies implemented by the new centre-left government since 2003. This campaign, popularly known as FRENAPO (National Front Against Poverty), was organised in the context of the implementation of neo-liberal macroeconomic policies in Argentina, which led the country to the biggest crisis in its history at the end of 2001. The members of the campaign proposed a package of economic and social measures oriented to unemployed workers (a basic income grant plus a professional education scheme), to the children and to the elderly (a basic income grant for both). The proposal was supported in a referendum by more than three million people all over the country during December 2001, but it was not considered by the Parliament. Although the alliance that supported FRENAPO eventually crumbled, the campaign was successful in its objective of influencing the public debates on how to respond to poverty and extreme poverty. Several measures implemented by the new centre-left government since 2003 were inspired by those debates, particularly those aimed at guaranteeing an income for children and the elderly. This article analyses the context of the campaign, identifies its concrete goals, origins and members, and explains how FRENAPO built power in order to achieve those objectives. Finally, it addresses the main consequences of FRENAPO, both in the short and long term, and highlights its lessons for future campaigns.
\end{abstract}

If today concepts like 'Asignación Universal por Hijo', Plan Jefes y Jefas de Familia' o 'Seguro para la vejez' sound familiar, that is because, among other reasons, ten years ago the Argentinean Workers Union took the political decision of organising a big rally (Marcha Grande) to eliminate the poor households in our country (Del Frade, 2010:n.p.).

\section{A Brief Overview of the National Front Against Poverty ${ }^{2}$}

This article analyses a campaign furthered and developed by a number of social organisations in Argentina at the end of the 1990s. The main objective of the National Front Against Poverty (FRENAPO) was to push the government to carry out measures that would eliminate poverty and extreme poverty. The article also discusses this campaign's results and impact in the following years, highlighting not only its direct impact but also its indirect medium-term consequences, particularly how the public debates since 2003 related to the new centre-left government's social policies.

During the 1990s Argentina's economy had a neo-liberal orientation. In particular, the

Global Labour Journal, 2015, 6(3), Page 351 
government implemented a structural adjustment programme consisting of - among other measures - the privatisation of public-owned enterprises, an international open-market orientation and the deregulation of numerous sectors of the economy. The consequences of this macroeconomic framework were devastating for the working class in Argentina. Within a few years the unemployment rate climbed to $18 \%$ (compared to an average $6 \%$ during the 1980 s), and the levels of poverty and extreme poverty became the highest in the history of the country, at least in the second half of twentieth century. ${ }^{3}$

The resistance against these policies was led by unions and unemployed workers' movements, but also included other groups such as organisations of peasants and indigenous groups, human rights organisations, political parties and artists. These organisations proposed several measures to fight against poverty and extreme poverty, some of which constituted the core of the campaign known as the National Front Against Poverty. This campaign pointed out that the labour market was incapable of responding to the challenge of dealing with poverty and extreme poverty, and that it was thus necessary to push for new measures linked to citizenship rights rather than solely to labour rights. In particular, FRENAPO proposed a package of economic and social measures oriented to unemployed workers, children and elderly people - a basic income grant for all three groups, as well as a professional education scheme for unemployed workers.

Initially the campaign was focused on ensuring that the government called for a binding referendum on the implementation of these measures. However, Argentina's 2001 political situation meant that the organisers were faced with insurmountable obstacles. Hence, there was a political decision to put forward an informal referendum; this took place between 14 and 17 December 2001. The proposal was supported by more than three million people all over the country. However, it could not be presented to the Parliament due to the political turmoil that Argentina faced towards the end of 2001. (Between 20 December 2001 and 5 January 2002, Argentina had five different presidents).

However, the campaign succeeded in its objective of influencing public debate on dealing with poverty and extreme poverty, and determined the orientation of the new government's social policies. In particular, the centre-left wing Kirchnerist administration that has governed the country since 2003 furthered a supplementary security income benefit for children and elderly people. Despite the fact that these initiatives did not fit with the original FRENAPO proposals, they represented the campaign's guidelines. Thus it is possible to conclude that the campaign stressed the need for specific measures to fight poverty and extreme poverty, and that these measures should not be constrained by the formal labour market.

In the first part of this article I analyse the context of the campaign. In particular, I describe Argentina's main economic features during the 1990s and their impact upon the labour market, focusing particularly on the levels of poverty, extreme poverty and inequality. Secondly, the article identifies the specific goals of the campaign, and describes its origins and members, as well as dealing with how FRENAPO built power in order to achieve those objectives. Finally, this paper discusses FRENAPO's political implications both in the short and long term, and highlights its lessons for future campaigns.

\section{Neo-liberal Hegemony and the Reasons behind FRENAPO}

The origins of the neo-liberal policies in Argentina can be traced back to the military government that ruled the country between 1976 and 1983. Despite that fact, its main consequences upon the labour market did not come to light until the 1990s. By that time Argentina was considered to be the 'best student' the international economic institutions - the International Monetary Fund (IMF) and the World Bank - could ask for, and the government pursued the path suggested by the 


\section{Washington Consensus. ${ }^{4}$}

It is beyond the scope of this article to explain the reasons behind the implementation of neoliberal policies in Argentina. It is possible to say, though, that a combination of both internal and external causes put an end to the welfare state developed between the 1940s and the 1970s. By the mid-1970s, the political and economic crisis in Argentina had become deeper as a result of the impact of the international economic crisis. The 1976 coup d'état, which included around 30000 missing people, most of them political activists and trade unionists, resulted in a huge change in the relation of forces, which weakened working-class resistance to neo-liberal policies. The main consequence of this change was that capital was able to restart the accumulation process, increasing the rate of profit.

Thus neo-liberalism was not a consequence of a bourgeois mastermind, but the specific way capital found to re-establish its hegemony. In other words, neo-liberalism was a new stage in the history of capitalist accumulation, characterised by a specific set of policies, after the exhaustion of the welfare state. Of course Argentina was not the only country facing these changes, although neoliberal policies can and do vary from country to country. However, it is not possible to analyse the emergence of FRENAPO and its proposals and limits without considering the specific consequences of neo-liberal policies, particularly in the labour market.

This process was devastating for the working class. As is shown in Figure 1 and Figure 2, the average real wage in 2001 was $43 \%$ less than in 1975, the unemployment rate climbed to a $18.3 \%$ of the economically active population, and underemployment was 16.3\% (against an average rate of 5$6 \%$ until the 1980s), while unregistered workers at the time climbed to $38.8 \%{ }^{5}$

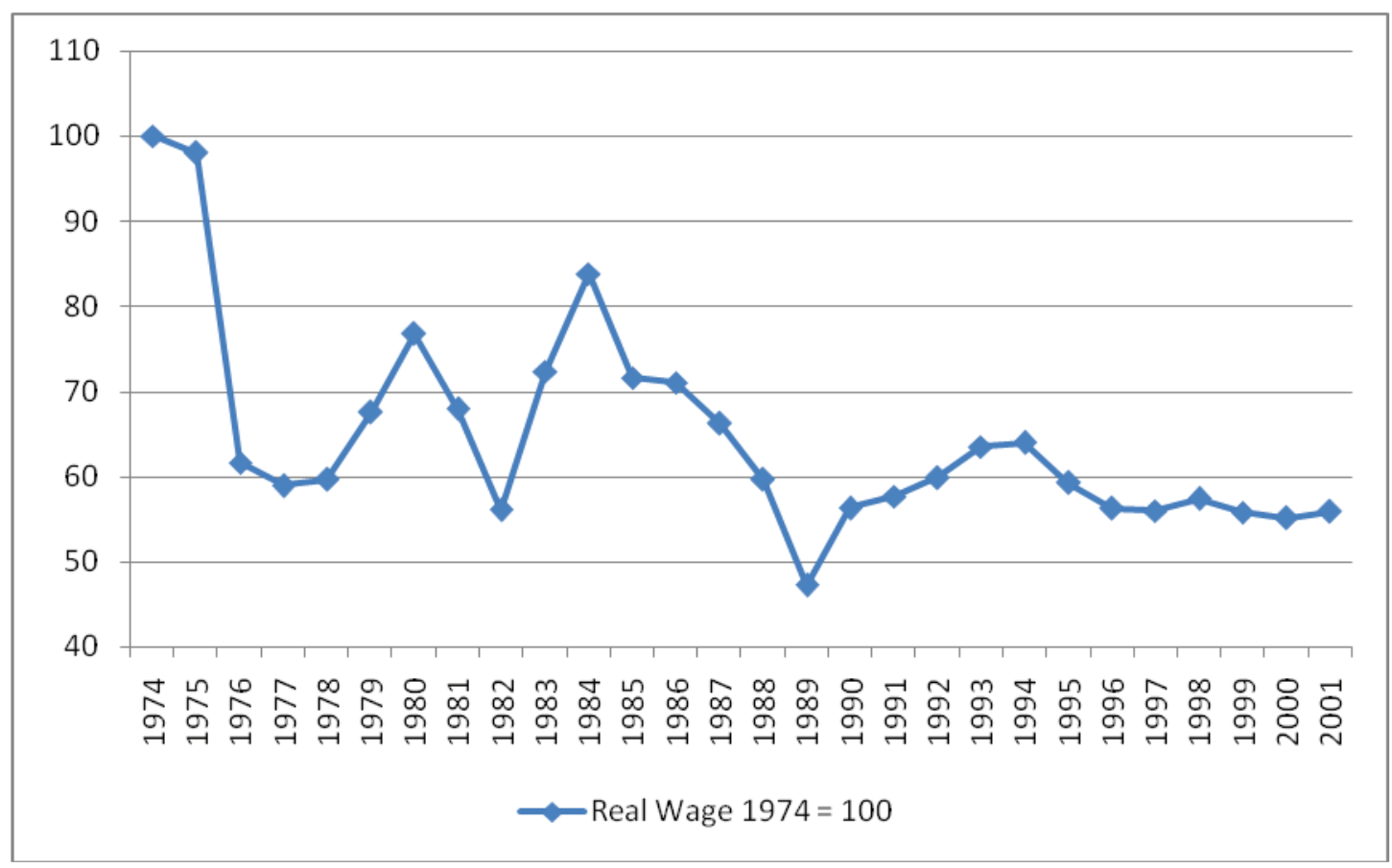

Source: Graña and Kennedy (2008)

Figure 1: Real wages, 1974-2001 


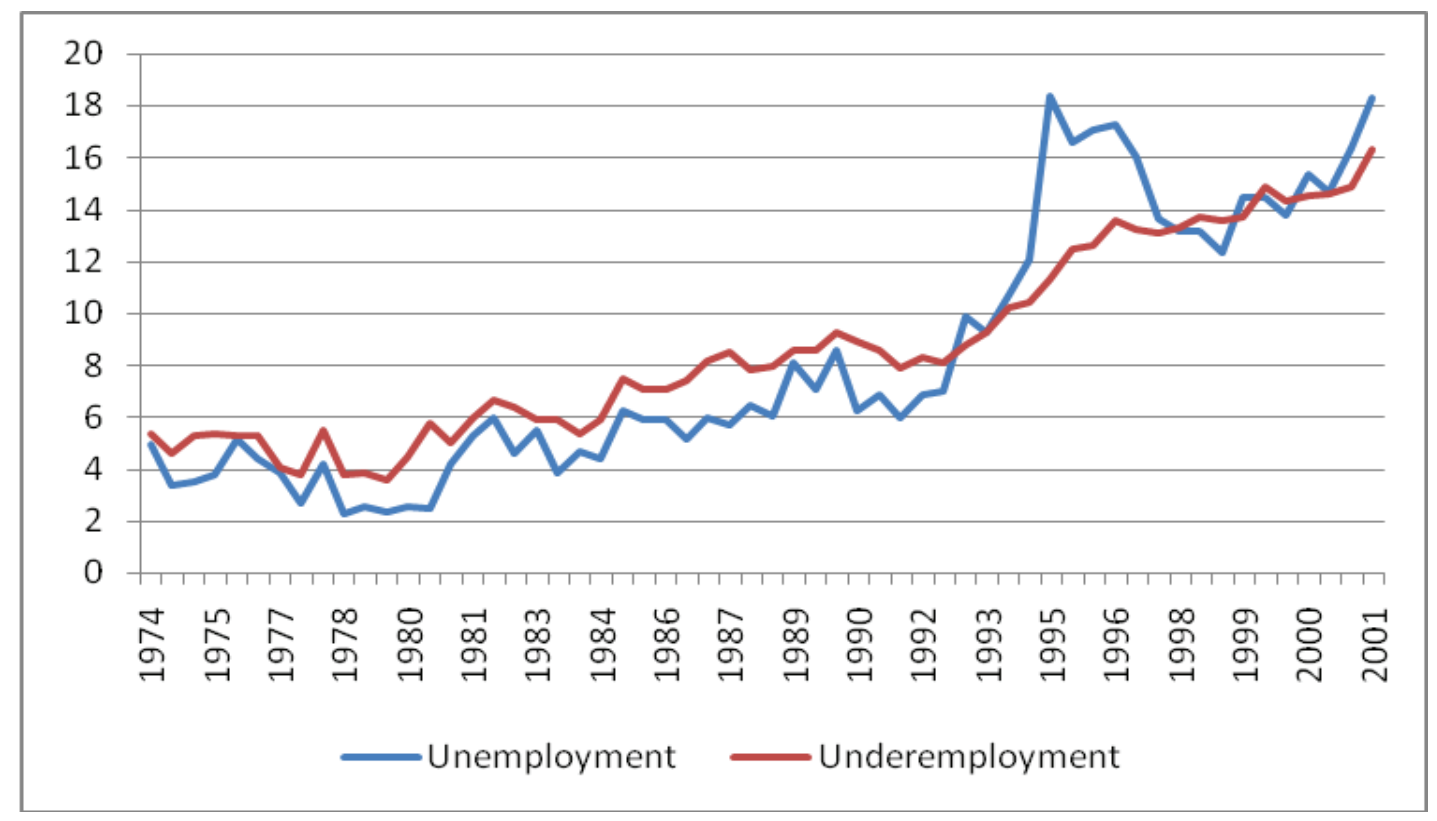

Source: National Institute on Statistic and Census (INDEC).

Figure 2: Rate of unemployment and underemployment, 1974-2001

In addition to those rates, inequality levels rose dramatically from 1975 to 2001. Taking into consideration personal income distribution levels, in 1975 the richest $10 \%$ of the population earned 5.4 times the income of the poorest 10\%, while in 2001 this gap grew to 29.7 times. It is also revealing to examine the trajectory of inequality levels during the last decade, given the fact that the Argentinean economy had experienced a strong recovery before its collapse in 2001 (GDP grew almost 80\% between 2001 and 2012), which allowed an improvement in the income distribution pattern: in 2012 the difference between the richest $10 \%$ and the poorest $10 \%$ was 18.6 times. Nevertheless, it is also true that the current gap is larger than that of the mid-1970s (Agis, Cañete and Panigo, 2010; INDEC, 2001, 2012). The Gini Index is another way to assess inequality - the closer the value is to 0 , the more equal the society; the closer it is to 1 , the less equal the society. This index also pointed to the idea of a massive deterioration in wages during those years. While in 1974 the Gini coefficient was 0.36 , in 2000 it reached 0.51 , its highest level since it was considered in the official statistics (Altmir, Beccaria and Rosada, 2002). ${ }^{6}$

Finally, during the neo-liberal period poverty and extreme poverty reached the highest levels in the country's history, climbing from values of $4.4 \%$ of the population in poverty and $2 \%$ in extreme poverty in 1974 , to $38.3 \%$ and $13.6 \%$ respectively in 2001 (Agis et al., 2010; INDEC, 2001). That meant that 14 million people were living in poverty, and half of them were children under eighteen years old. This was probably the most significant result of being the 'best student' of the international economic institutions. At the same time it contributed to setting the grounds for the working-class resistance against neo-liberal policies that began during the early 1990s.

Initially there was no coordination among the organisations leading the resistance. There were 
diverse reactions, mainly organised by public workers' unions and unemployed workers' movements, particularly in small cities and towns that were affected by the privatisation of public companies and the rise in unemployment levels.

By the middle of the 1990s social conflict emerged on a daily basis in northern provinces such as Jujuy, Santiago del Estero and Salta, and southern provinces such Neuquén, Río Negro and Tierra del Fuego. The most common action carried out by protesters was the blockage of streets and roads. ${ }^{7}$

Although there were countless protests during those years, it is possible to identify some important landmarks in this process:

- In 1991 the government decided to close an iron mine in Sierra Grande (in Río Negro province). As a result of this decision, more than 1000 workers lost their jobs and began a protest that involved - among a broad repertory of strategies - the blocking of a national highway.

- In 1993 Santiago del Estero's local parliament passed an adjustment law that implied the layoff of thousands of public workers and a reduction in their wages. In response, the local union movement protested in the streets for many days. The demonstrations against the government ended only after the local parliament was set on fire in December 1993.

- In 1995 the first killing of a social activist (Víctor Choque) took place in the province of Tierra del Fuego, when the police repressed a group of workers who were occupying a metal factory because their employer had not paid their salaries.

- In the provinces of Salta and Neuquén, protests started as a consequence of the privatisation of the national oil company (YPF), which resulted in numerous dismissals of workers. In small towns such as Cutral-Co and Plaza Huincul in Neuquén, and Tartagal in Salta, the blocking of national routes became the main strategy to put forward a strong protest against the government, who usually responded with both local and national police repression of the demonstrators. As a result of this repression, in 1996 Teresa Rodriguez was killed by the local police in the province of Neuquén.

- In 1997 there were at least 104 blockages of national or provincial routes, which was ten times the annual average of the blockages that had taken place between 1989 and 1996.

Police repression did not put a stop to the demonstrations. On the contrary, mobilisation grew and slowly reached the heart of big cities, in particular Buenos Aires and its outskirts, where $40 \%$ of the total population of the country lives.

It is important to draw attention to the demonstrations' geographical distribution because this was closely related to the features of these resistance strategies. Indeed, it was only possible to put forward a nationally coordinated campaign once the social and political struggles reached the largest cities of the country. (The biggest demonstrations between 1993 and 1999 took place more than $1500 \mathrm{~km}$ away from Buenos Aires, which had become the centre of the protests by 2000.) By the end of the 1990s the crisis had become national, and the resistance against the social consequences of neo-liberal economic policies followed a similar path. As soon as this resistance became deeper, the different social movements that were already participating decided to coordinate more closely.

Initially coordination involved the joint participation of unions, unemployed workers' organisations and social movements in general in the organisation of specific activities - for example, a huge demonstration that marched throughout the country in 1994 (the Marcha Federal),

Global Labour Journal, 2015, 6(3), Page 355 
six general strikes between 1995 and 1997, and the national protest of the Teachers' Union (CTERA) between 1997 and 1999. ${ }^{8}$ The participation and commitment of a national organisation was certainly necessary to plan and coordinate articulated responses.

The Argentinean Workers' Union (CTA) played a key role throughout this process. This federation was founded in 1991 by a group of unions that broke with the General Workers Confederation (CGT), criticising its support of the neo-liberal government. ${ }^{9}$ The core principle of the CTA consisted of its independence from employers, political parties and the government. This independence allowed the CTA to support the resistance movement against the government's economic policies as well as to establish alliances with other social organisations besides trade unions. The CTA's responses to the changes in the formal labour market consisted of actions related not only to labour rights, but also to public services and housing rights, in alliance with other locally based organisations. This strategy allowed the CTA to increase its membership in the informal sector and the unemployed - groupings which consisted of more than half the labour force in Argentina during the 1990 s.

One of the largest alliances was known as FRENAPO, whose origins can be traced back to the joint activity of trade unions and social movements during the decade of the 1990s. The CTA was by far the largest promoter of this alliance.

The first step in building FRENAPO was the Marcha Grande, which stretched $300 \mathrm{~km}$, from the city of Rosario in Santa Fe to the capital city of Buenos Aires. The march began in Rosario on 26 July 2000, and reached Buenos Aires two weeks later. The demonstrators pleaded for a referendum that would force the government to implement a training and employment programme for unemployed householders and a basic income grant for children.

Although the CTA was the chief organiser, the mobilisation was supported by numerous other organisations such as unemployed workers' organisations, human rights organisations and leftwing political parties as well as by a small group of union leaders of the CGT. In addition, it also received the solidarity of union federations from other South American countries.

Based on the experience of the Marcha Grande, in December 2000 these organisations decided to create a formal alliance as a strategy to push for those demands. The first name it got was the Movement for the Referendum; a call for a basic income grant for elderly people was added to the list of demands. A few months later, in July 2001, the name of the movement was changed to National Front Against Poverty. It was then that FRENAPO made its first official public appearance and established the path towards the 'popular referendum' that would take place five months later.

\section{The Campaign: Its Members, Objectives and Development}

As was stated above, the CTA was the largest promoter and supporter of FRENAPO. Nevertheless, its leaders believed that the campaign had to be based upon a broader alliance in order to allow other organisations to participate without having to subordinate themselves to the CTA's general strategy. In that sense, FRENAPO worked like an umbrella organisation, allowing any organisation that wanted to take part in its activities to do so. In other words, the CTA assumed a position as first among equals, thus opening the door to other organisations that would not have taken part in a 'union-based' campaign.

The first steps in the creation of FRENAPO were taken by a diverse group of social organisations whose activities were linked to issues like housing rights, health rights and human rights in addition to its main goal of workers' rights. It also included some employers' organisations (small and medium enterprises), and small and medium farmers' organisations. In March 2001 they also created a National Board, which was in charge of promoting the activities of FRENAPO. Table 1 shows the main organisations that took part in the creation of FRENAPO. It is also important to

Global Labour Journal, 2015, 6(3), Page 356 
mention that later on many others decided to support the campaign, in particular individuals such as artists, religious leaders, politicians and sportsmen (Del Frade, 2011).

In order to encourage participation in the campaign - which was an explicit objective of the alliance's members - it was established that any member of the Board could suggest the incorporation of any other organisation or individuals, with the only requirement that they had to share the campaign's objectives. The informal structure of the campaign played an important role in achieving this goal. Indeed, the campaign successfully promoted this by means of its informal organisational structure: on one hand, there was a simple and specific objective with a simple and specific proposal; on the other hand, the alliance's internal structure was so informal that it allowed all sorts of participation.

\section{Table 1. Founding members of FRENAPO}

\begin{tabular}{|l|l|}
\hline Organisation & Field of activity \\
\hline Argentinean Workers' Union (CTA) & Trade union \\
\hline Public Workers Association (ATE) & Trade union \\
\hline Argentinean Education Workers Confederation (CTERA) & Trade union \\
\hline Tire Workers Union (SUTNA) & Trade union \\
\hline Argentinean Judiciary Federation (FJA) & Trade union \\
\hline Land and Housing Federation (FTV) & Unemployed movement \\
\hline Classist and Combative Movement (CCC) & Unemployed movement \\
\hline Mothers of May Square & Human rights \\
\hline Grandmothers of May Square & Human rights \\
\hline Ecumenical Movement for Human Rights (MEDH) & Human rights \\
\hline Peace and Justice Service (SERPAJ) & Human rights \\
\hline Centre of Legal and Social Studies (CELS) & Human rights \\
\hline Assembly of Small and Medium Enterprises (APyME) & $\begin{array}{l}\text { Small and medium } \\
\text { enterprises }\end{array}$ \\
\hline Argentinean Rural Federation (FAA) & Small farmers \\
\hline Cooperative Funds Institute (IMFC) & Cooperatives \\
\hline
\end{tabular}

The creation of a broad alliance was one of the strengths of FRENAPO, since it ensured strong support for its proposals among different social sectors. In addition to this, it contributed to building a general consensus in society that measures proposed by FRENAPO were not a sectoral complaint, but a necessity for the society as a whole.

Before joining FRENAPO, the alliance members had identified poverty as the most imperative problem in Argentina. In fact, many of them had played an important role throughout the protests during the 1990 s. So, the alliance created an opportunity to pursue the implementation of certain measures in order to alter the pattern of income distribution, in the understanding that 
the macroeconomic policies followed by the government were incapable of dealing with those issues. By the time of its foundation, there was no necessity for a strong debate among the FRENAPO members about the priorities that would move such an initiative.

Behind this idea was the assumption that an explicit objective of those macroeconomic policies was to increase poverty and extreme poverty. From this point of view, the FRENAPO campaign can also be understood as an important step in the resistance against neo-liberalism in Argentina, from both ideological and organisational perspectives. On the one hand, it contributed to the creation of a strong opposition to neo-liberal ideas, mainly those which explain economic problems as a result of state interventions in the economy and posit that the solutions would come from market-based economic policies. ${ }^{10}$ On the other hand, the campaign was able to build a broad consensus between various organisations with different political perspectives, which turned out to be very important in the political scenario after the collapse of the political and economic system at the end of 2001.

The strength of the campaign also lay in the simplicity of its core idea. FRENAPO stressed that there were plenty of resources in the country, but that there was a problem regarding their distribution among the population. In other words, they believed that it was possible to establish different strategies to alter the distribution of these resources and thus to end poverty and extreme poverty.

In order to achieve these objectives, the FRENAPO plan included: ${ }^{11}$

- A basic income grant for every unemployed worker. The amount of this grant was set as $\mathrm{A} \$ 380^{12}$ per month, which had to be followed by an education and training programme for the beneficiaries.

- A basic income grant for each child under 18 years old, equal to $A \$ 60$ per month.

- A basic income grant for elderly people over 65 years, equal to the minimum pension of A $\$ 150$ per month.

The amount of the grants was determined by considering what resources were vital for a family to satisfy its basic needs. By October 2001, the National Institute on Statistics and Census established that a family of five people (two adults and three children) needed A $\$ 504$ per month to live above the poverty line and $\mathrm{A} \$ 205$ per month to live above the extreme poverty line.

The FRENAPO programme pointed to potential economic resources that could go into the grants, and how this should be put into practice. The specific economic calculations were provided by FRENAPO economists. These calculations were quite important because they tried to show that the campaign was not a mere complaint about the consequences of the neo-liberal macroeconomic policies, but a comprehensive proposal based upon an entirely different orientation towards the country's economy (even though it did not imply a radical change in the social relations of production).

Overall, the measures posited by FRENAPO required $A \$ 9700$ million per year. This amount of money could have been drawn from different sources, such as:

- the elimination of income tax exemptions (A\$5 700 million);

- the removal of tax benefits for banks, large retail companies and privatised public service companies (A\$1 500 million);

- the creation of a new tax on luxury goods (A $\$ 1000$ million);

Global Labour Journal, 2015, 6(3), Page 358 
- the reallocation of existing resources on social policies (A $\$ 1000$ million); and

- the removal of subsides for privatised companies (A\$500 million).

The first objective of the campaign was, as stated above, to push for a mandatory referendum that, according to Article 40 of the National Constitution, required the approval of the National Parliament. This procedure enables the Parliament to submit a legal initiative for consideration of the people by means of a compulsory referendum. However, the FRENAPO leadership soon realised that the government was not planning to permit such an initiative. Consequently, they decided to turn the campaign into a massive political denouncement of the neo-liberal economic framework and its consequences. The mandatory referendum, therefore, became an informal referendum, which was organised and carried out by FRENAPO from 14 to 17 December 2001.

In the months preceding the referendum, FRENAPO's activity was quite intense. It included the participation of its members in massive demonstrations around the country, such as the one against the implementation of the America Free Trade Area (ALCA) initiative in April, a national strike in August and a march to the National Parliament in October. These activities were part of the resistance against neo-liberalism in Argentina, and FRENAPO members took part in all of them, even if they were not organised by the alliance.

The most important demonstration organised by FRENAPO took place in September 2001, when seven groups of militants departed from Buenos Aires and headed towards different key regions of the country. Each group was led by a FRENAPO member and had the mission of organising meetings along the way to discuss and publicise the programme. The campaign process took nearly a full year, from its initial steps in December 2000 to the holding of the informal referendum in December 2001.

In the meantime, the structure of the alliance had become more complex, although without losing its original flexibility. This structure combined national and local levels. On the one hand, it had a national coordination committee that reached its decisions by consensus, and was responsible for the elaboration of the campaign's general guidelines (in particular, preparation and distribution of ballot papers and boxes, and the establishment of relationships with national media and government authorities).

On the other hand, there were numerous local committees throughout the entire country. In fact, the development of the entire campaign was possible because of these local FRENAPO committees that were created whenever and wherever possible. These committees were responsible for the propaganda and coordination of the campaign at local level. They also gave prominence to local organisations, and contributed to strengthening linkages at the local level. Although there was a national coordination committee, the heart of the FRENAPO campaign was based on these local milestones. In fact, the rules of the Movement for the Referendum stated that it would be an independent decision of the local organisations on how to organise the activities, the funding and the location of the FRENAPO office at the local level, with the only limitation being that they had to respect the objectives of the campaign. Initially fifty-six local committees were created, but later many more were founded throughout the country. This decentralisation was an important issue in the structure of FRENAPO, and it helped to avoid the accusation that the alliance was an initiative that concerned only the big cities. There is no information about how many local committees were created before the referendum took place in December 2001, but many members of FRENAPO said that there were at least a hundred committees all around the country.

Trade unions played a key role in these committees, and many of them were founded in union buildings and funded by unions. (Although there was no specific rule on how to fund the activities of FRENAPO, most were supported by the unions, which were the biggest organisations within the

Global Labour Journal, 2015, 6(3), Page 359 
alliance.) This particular structure allowed the participants to organise periodic meetings and to adjust the strategy to each region's specific needs (whether they were big cities or small towns). Once again, there were no national guidelines on how to function at the local level. The only general suggestion was that all the activities had to focus on the general objective of guaranteeing popular participation in the referendum.

The referendum started on 14 December 2001, and took place over four days. During those days FRENAPO sent over 20000 ballot boxes throughout the country. Each of them was not only a place of voting, but also a space to deepen the propaganda strategy, gathering people together and furthering the proposal's discussion. The referendum turned into a massive mobilisation of social and political militants throughout the country, and each voting place became a site of debate among the electors. Despite the fact that it was not a formal space of discussion, militants used it to further their political perspectives regarding the alliance and the local political situation.

The result of the referendum was powerful: over 3.1 million people supported the proposal and only 20000 people rejected it. This was the biggest public rejection of the consequences of the neo-liberal economic policies in over a decade. In order to allow a comparison, it is possible to note that in the 2003 presidential election almost 20 million people voted, which means that around 15\% of the effective voters in a mandatory election decided to take part in the FRENAPO referendum.

Once the referendum was finished, the question was what to do with this huge support and how to turn it into political, social and economic change. FRENAPO was unable to respond to that challenge. This was one of the most important weaknesses of the campaign. There should have been a plan for the day after the referendum, but FRENAPO did not think beyond the campaign. After years of resistance against neo-liberalism, and after a huge mobilisation around a concrete proposal, the members of the alliance did not know what to do with the political power they had accumulated throughout the campaign. As a consequence of this weakness, FRENAPO was unable to function as the leader of the political process that emerged after the crisis that Argentina faced just a few days after the campaign.

\section{FRENAPO from the 2001 Crisis to the Universal Child Allocation}

There are many factors that help to explain why the FRENAPO programme could not be achieved. The first of them is related to the economic situation that Argentina faced from the end of the 1990s until the end of 2002: its economy was in recession during that period, the longest in the history of the country.

The popular referendum organised by FRENAPO took place on December 2001. Two days later, hundreds of demonstrations throughout the country demanded the resignation of the president and a deep and complete change in the country's economic policies. The last chapter of this story is well known. The government repressed the protests, killing more than thirty people throughout the last days of December 2001. Nevertheless, the president was forced to resign and Argentina experienced a period of political and economic instability, which included the succession of five different presidents in a few weeks, the devaluation of the national currency, and the default on its external debt. By the end of 2001 FRENAPO had a proposal supported by more than three million people, but there was no functioning government to receive and analyse it.

The already critical social situation became even worse throughout 2002. The unemployment rate jumped to $21.5 \%$, poverty to $57.5 \%$ and extreme poverty reached $27.5 \%$. In January 2002 Eduardo Duhalde was appointed as national president by the Parliament; he ruled the country until May 2003. In this particular context the proposal of FRENAPO was still relevant; the transitional government took its main idea and implemented the Unemployed Heads of Household Programme (Plan Jefes y Jefas de Hogar Desocupados).

Global Labour Journal, 2015, 6(3), Page 360 
This social programme established an income grant of $A \$ 150$ for every unemployed householder. It was implemented in less than three months, and reached over two million people. However, it is not possible to match this programme with that of FRENAPO, whose members did not participate in the design of this one. For one thing, the amount of money assigned by the Plan Jefes y Jefas was not enough to raise people above the poverty line; as a matter of fact, it represented only about one-third of the FRENAPO proposal. In addition, there was no specific consideration for children and elderly people. Moreover, the government decided to close the entry to the programme in June 2002, thus denying access to newly unemployed people. These restrictions denatured the FRENAPO objectives, and many of its members strongly criticised the Plan Jefes $y$ Jefas, pointing out that it was a bad copy of the proposal supported by the campaign in December 2001.

In 2003 general elections resulted in the formation of a new centre-left government. Faced with the social crisis, its first reaction was to decide that poverty and extreme poverty should be considered from the perspective of labour-market institutions. Indeed, the government stated that the priority was to create employment and to strengthen formal labour relations. Once again, the FRENAPO proposal was not considered as a valid measure to respond to the social crisis. (The proposal of the campaign was renewed by the CTA in 2005 but it was rejected by the government [Rameri, Raffo and Lozano, 2005].)

The strategy focused on the labour market institutions was quite successful for a time unemployment rates decreased from $17.3 \%$ in 2003 to $8.5 \%$ in 2007, and the rate of informal workers decreased from $45.1 \%$ in 2003 to $40.4 \%$ in 2007 (INDEC, 2003, 2007). However, the dynamism of the labour market became weaker in 2007 and the social question was again put at the centre of public debates, especially after the economic crisis towards the end of 2008.

The government realised that a different approach to deal with these issues was necessary and in 2009, after a defeat in the mid-term elections, decided to introduce a significant change in its social policy. The spirit of the FRENAPO proposal returned in the form of a measure that implemented a conditional cash transfer programme known as Asignación Universal por Hijo (Universal Child Allocation, AUH). This programme provided for a transfer of money to the parents of poor households for each child under 18 years old. The amount of the grant was originally A\$180 per child per month, ${ }^{13}$ and the programme required that both parents were unemployed or not earning more than the minimum wage. The AUH has been the largest social programme in Argentinean history, assisting around 3.7 million children, and despite its critics, the impressive results are undeniable (Dobrusin, 2010).

The implementation of this programme was followed by an important change in the pension system. In particular, the government took two measures that were quite remarkable. In 2008 the pension system was nationalised after its privatisation in 1994; in addition, the government implemented a mechanism to facilitate access to a minimum pension for every adult over 65 years of age.

It is possible to consider these two initiatives - the AUH and the changes in the pension system - to be part of the legacy of the FRENAPO campaign. As was stated above, FRENAPO was unable to go beyond the campaign, and the alliance itself broke up after the election of a new centre-left administration in 2003. However, most of its ideas influenced the social policies implemented throughout the decade that followed its peak.

By the middle of the first decade of the twenty-first century, the FRENAPO alliance was definitely over. As soon as the new government implemented, at least partially, the agenda that was supported by these 1990s social movements (unions, unemployed organisations, human rights NGOs, etc), several of them decided to strongly support the new government, while others

Global Labour Journal, 2015, 6(3), Page 361 
remained in political opposition, and the FRENAPO alliance followed the same path. Its failure as a political alliance contrasts with its success in the field of ideological debates.

\section{Conclusion}

The experience of FRENAPO was one of the highest points in the resistance against neoliberalism in Argentina. It showed that it was possible to build a broad consensus to fight against the consequences of the prevailing neo-liberal economic framework. In particular, it gave voice to those who claimed that the levels of poverty and extreme poverty were unacceptable.

There are many key lessons that explain why FRENAPO was successful. In particular, it is important to highlight that the alliance was able to combine local and national strategies, giving space to both national and locally based organisations to participate.

The Argentinean Workers' Union played an important role in the campaign. Although it was the largest organisation within the alliance by far, it did not push for a strategy solely based on labour rights and the traditional union agenda. The FRENAPO campaign justified its proposal linking the specific measures with citizenship rights, and that enabled the participation in the campaign of many social organisations which were not directly involved in labour issues.

The very existence of FRENAPO is a valuable lesson. Indeed, had the same programme been put forward by the CTA on its own, it would not have been possible to build such a broad consensus around the proposal. The CTA did not monopolise conduct within the alliance, opening spaces for the rest of the members of the alliance to occupy positions in the campaign. Still, as many leaders of FRENAPO recognised, the campaign was only successful as a defensive strategy. Víctor De Gennaro, former General Secretary of the CTA, some years later had accepted that while the popular referendum was a means for people to reject certain policies, it had not been enough to develop a real alliance that could govern the country.

Hence, one of the weaknesses of FRENAPO lay in its own conception. The basic idea of the proposal was that there were plenty of resources in the Argentinean economy, thus the problem was merely one of income redistribution. This starting point did not take into account that Argentina was facing a huge economic crisis and that implementing the measures that FRENAPO was pushing for would have required a complete change in the neo-liberal economic framework.

The origins of this crisis could be traced back to the economic policies implemented by the military government between 1976 and 1983, which were reinforced after 1991 by a centre-right government. As a consequence of these measures, the Argentinean economy was ruled for more than two decades by financial capital, which subordinated the rest of the economy, particularly industry, to its own interests. This meant that the FRENAPO initiative was not only fighting against the social consequences of that economic framework. That is, the real meaning of the FRENAPO proposal implied not only a single problem of income redistribution, but a broad objection to the economic, social and political order that had ruled the country since 1976.

The FRENAPO campaign had no strategy to deal with this bigger challenge. In order to have such a strategy, it would have been necessary to have many more political and economic discussions and definitions, which would have probably put many obstacles in the process of building a broad alliance. At that point, it was possible to confront the ruling economic and political order during the 1990s, but it was not so simple to elaborate a comprehensive proposal on what to do after neoliberalism. FRENAPO would have faced a dilemma it was not prepared for: Was it its main objective to go beyond capitalism? Or was the objective just to re-establish the welfare state in Argentina? And was it possible, given the changes in global capitalism at the beginning of the twenty-first century, to go back to an accumulation pattern based on an internal market and wealth redistribution?

Global Labour Journal, 2015, 6(3), Page 362 
From this point of view, the FRENAPO campaign could only allow numerous organisations and people to channel their frustration because of the consequences of twenty-five years of neoliberalism. Once they had expressed that frustration, it was necessary to show them what to do about numerous key issues in the economic and political fields. The organisations that supported the FRENAPO campaign had no solid answers to this bigger challenge, and the broad alliance eventually crumbled. In particular, the arrival of a centre-left government in Argentina in 2003 was the last chapter in the alliance, since many organisations joined the government.

These are the main sources of the failure and success of FRENAPO. As we have described, the campaign could not achieve its objectives. Nevertheless, it had a strong influence in the following years since it was able to build a social consensus around the importance of universal social policies. In particular, two of the most important social measures implemented by the new administration the Universal Child Allocation and the changes in the pension system - are part of FRENAPO's legacy. From this point of view, it can be stressed that the campaign which developed in December 2001, in the middle of the largest economic crisis that Argentina faced in its history, was quite successful. Not only did it stop the increase of poverty, extreme poverty and inequality, but it also defined the limits of the discussion around the social policies for the following decade.

\section{NOTES}

${ }^{1}$ The author would like to thank Michelle Williams and Florencia Rodríguez for comments on previous versions of this article.

${ }^{2}$ I joined the FRENAPO in 2000 as a member of a human rights organisation. The information used for this article comes from different sources, including my own experience during those months. The final conclusions are part of a debate that took place in the following years with colleagues who were part of that experience.

${ }^{3}$ There is no statistical information about the unemployment rate, poverty or extreme poverty prior to the 1950s or, in certain cases, the 1970s. Thus it is not possible to extend this comparison to the first half of the twentieth century.

${ }^{4}$ This path included different measures such as the privatisation of state companies, the deregulation of the economy (in particular of the labour market), the liberalisation of trade (in particular the removal of import barriers) and the securitisation of property rights.

${ }^{5}$ Non-registered workers do not have access to the social security system (public pension system, protection in case of diseases or accidents, etc.), and they are not covered by the collective bargaining process. In Argentina this category is used as a measure of the informalisation of the labour market.

${ }^{6}$ The Gini Index also suggested an improvement during the last decade, reaching 0.41 in 2012.

${ }^{7}$ In Argentina we define the blockage of a street or road as a piquete, so the people who take part in that action are known as piqueteros. By the end of the 1990s there were many organisations that defined themselves as piqueteros. The content of their claims was quite similar; they demanded mainly jobs, but also food and houses; they also demonstrated because of the situation of the public service in general.

${ }^{8}$ This protest consisted of placing a large tent in front of the national parliament as part of an action claiming an increase in the education budget. Many teachers coming from all over the country lived in the tent for several weeks, before being replaced by the next group. The tent, known as the White Tent, became a place of meeting for different social and political movements that supported

Global Labour Journal, 2015, 6(3), Page 363 
the protest of the teachers, including other unions, political parties, artists, sportsmen, etc. It is possible to see in this protest one important antecedent of the FRENAPO campaign.

9 The CGT was founded in 1930 and is the biggest federation in Argentina. Its affiliates are industrial organisations, its main objective is related to the working conditions of formal workers, and its strategy has been characterised as neo-corporatist. CTA, on the other hand, has been described as a social movement union, whose objectives are not limited by the situation of formal workers. The CTA's strategy during the 1990s included claims for grants for unemployed people, demands for social policies such as building houses for poor people and massive access to health services, the recognition of land rights for peasants and indigenous people, etc. A brief overview of these two different approaches can be found in Etchemendy and Collier (2007) and Ferrero and Gurrera (2007).

${ }^{10}$ It is also interesting to note that today, over a decade years after the crisis in December 2001, the concept of structural adjustment still remains unpopular for the majority of the population, and for that reason it is not possible for the government to implement this kind of adjustment without facing strong opposition from the people.

11 The FRENAPO proposal was inspired by the theoretical approaches that suggested the importance of implementing public policies in order to guarantee a basic income for every citizen in each country. These ideas were developed in Europe by authors such as Van Parijs (2004). In Argentina there were also many authors who pushed for these kinds of measures during the 1990s, for example Lo Vuolo et al. (1998).

${ }^{12}$ By the time of FRENAPO, there was a fixed exchange rate with the US dollar $-1 \mathrm{~A} \$=1 \mathrm{US} \$$.

${ }^{13}$ In the following years the Universal Children Grant was periodically increased. In 2013 the rate was $\mathrm{A} \$ 460$ per child per month. Updating of the nominal value avoids deterioration in real terms. Because of inflation, the Universal Children Grant had a 17\% increase in real terms between 2009 and 2013.

\section{REFERENCES}

Agis, E., Cañete, C. and Panigo, D. (2010) El impacto de la asignación universal por hijo en Argentina. Working paper. Buenos Aires: CEIL-PIETTE.

Altmir, O., Beccaria, L. and González Rosada, M. (2002) La distribución del ingreso en Argentina, 1974-2000. Revista de la CEPAL, 78, December.

Del Frade, C. (2010) La Marcha Grande. A diez años del río místico de la historia argentina. Buenos Aires: Central de Trabajadores de la Argentina.

Del Frade, C. (2011) Crónicas del FRENAPO. El sueño colectivo inconcluso. La lucha por la igualdad y la riqueza. Buenos Aires: Central de Trabajadores de la Argentina.

Dobrusin, B. (2010) Social Protection and the State. Mimeo.

Etchementy, S. and Collier, R. (2007) Down But Not Out: Union Resurgence and Segmented Neocorporatism in Argentina (2003-2007). Politics and Society, 35(3): 363-401.

Ferrero, J. and Gurrera, M. (2007) El sindicalismo de movimiento social. Algunas reflexiones en torno del concepto. In Estado y sindicatos en perspectiva latinoamericana, edited by A. Fernández. Buenos Aires: Editorial Prometeo Libros.

Global Labour Journal, 2015, 6(3), Page 364 
Graña, J.M. and Kennedy, D. (2008) Salario real, costo laboural y productividad. Argentina 1947-2006. Análisis de la información y metodología de estimación. Working Paper n. 12. Buenos Aires: CEPED.

Lo Vuolo, R., Barbeito, A. and Pautassi, L. (1998) Pobreza y políticas de sostenimiento del ingreso. Asistencialismo focal isado vs. ingresos básicos universales. Buenos Aires: Centro Interdisciplinario para el Estudio de Políticas Públicas.

National Institute on Statistics and Census (INDEC). (2001) Permanent Household Survey 2001. Buenos Aires: INDEC.

National Institute on Statistics and Census (INDEC). (2003) Permanent Household Survey 2003. Buenos Aires: INDEC.

National Institute on Statistics and Census (INDEC). (2007) Permanent Household Survey 2007. Buenos Aires: INDEC.

National Institute on Statistics and Census (INDEC). (2012) Permanent Household Survey 2012. Buenos Aires: INDEC.

Rameri, A., Raffo, T. and Lozano, C. (2005) La universal isación de las asignaciones familiares y la actual isación de la propuesta del FRENAPO: distintas opciones. Buenos Aires: Instituto de Estudios y Formación de la CTA.

Van Parijs, P. (2004) Más allá de la solidaridad. Los fundamentos éticos del estado de bienestar y de su superación. In Contra la exclusión. La propuesta del Ingreso Ciudadano, edited by R. Lo Vuolo and A. Barbeito. Buenos Aires: Mino y Davila.

\section{BIOGRAPHICAL NOTE}

Luis Ernesto Campos has a post-doctoral fellowship from the National Council on Scientific and Technical Research (CONICET) in Argentina. He has a PhD in Social Science and a Masters in Political Economy from the Latin American Faculty of Social Science (FLACSO). He has been a member of the Argentinean Workers Union (CTA) since 2006 as a coordinator of the Social Rights Observatory. His research interests include the labour market, collective bargaining and labour conflict. In 2013 he was part of the Engage Programme at the University of the Witwatersrand.

Global Labour Journal, 2015, 6(3), Page 365 